\title{
Palm oil in diets for Nile tilapia (Oreochromis niloticus) post-larvae
}

\author{
Óleo de palma em dietas para pós-larvas de tilápia do Nilo (Oreochromis niloticus) \\ Aceite de palma en las dietas postlarva de tilapia del Nilo (Oreochromis niloticus)
}

Received: 10/21/2021 | Reviewed: 10/28/2021 | Accept: 11/08/2021| Published: 11/12/2021

\author{
Luiz Fernando de Souza Alves \\ ORCID: https://orcid.org/0000-0002-3639-9602 \\ Maringá Higher Education Center, Brazil \\ E-mail: luizferzoo@ hotmail.com \\ Joana D'Arc Maurício Rocha \\ ORCID: https://orcid.org/0000-0002-7131-2349 \\ State University of Amapá, Brazil \\ E-mail: joanadmrocha@hotmail.com \\ Matheus dos Santos Cardoso \\ ORCID: https://orcid.org/0000-0002-2572-0739 \\ State University of Western Paraná, Brazil \\ E-mail: msccardoso27@gmail.com \\ Jakeline Marcela Azambuja de Freitas \\ ORCID: https://orcid.org/0000-0001-8699-7291 \\ State University of Western Paraná, Brazil \\ E-mail: jakelinemarcela@hotmail.com \\ Aldi Feiden \\ ORCID: https://orcid.org/0000-0002-6823-9291 \\ State University of Western Paraná, Brazil \\ E-mail: aldifeiden@gmail.com \\ Wilson Rogério Boscolo \\ ORCID: https://orcid.org/0000-0002-1808-0518 \\ State University of Western Paraná, Brazil \\ E-mail: wilsonboscolo@hotmail.com
}

\begin{abstract}
The objectives of this research were to evaluate the effects of the substitution of soybean oil by palm oil in the diet of Nile tilapia (Oreochromis niloticus) post-larvae, to observe the performance and attractiveness of the feed, and to evaluate the fatty acid methyl esters profile of palm oil. Four hundred Nile tilapias were used after hatching (seven days old), distributed in 20 fiberglass tanks of $20 \mathrm{~L}$ each. The experiment was carried out in a completely randomized design with five treatments and four replicates. The treatments consisted of different levels of inclusion of palm oil, which were: $0.0,1.5,3.0,4.5$ and $6.0 \%$. The concentration of monounsaturated and saturated fatty acids in palm oil was measured, resulting in high amounts of palmitic, oleic and linoleic fatty acids. Significant differences were observed for the variables final weight, total length, weight gain, specific growth rate and condition factor. No significant differences were observed for palatability of the diets. It is concluded that the inclusion of $3 \%$ or more palm oil in substitution of soybean oil during the masculinization stage of tilapia larvae contributes to the improvement of productive parameters.
\end{abstract}

Keywords: Fish nutrition; Performance; Lipids; Oreochromis niloticus.

\section{Resumo}

A pesquisa objetivou avaliar os efeitos da substituição do óleo de soja pelo óleo de palma na dieta de pós-larvas de tilápia do Nilo, sobre o desempenho zootécnico e atrato-palatabilidade das rações bem como determinar o perfil dos ésteres metílicos de ácidos graxos do óleo de palma. Foram utilizadas 400 pós-larvas de tilápia do Nilo com sete dias após eclosão, distribuídas em 20 tanques de fibra de vidro de $20 \mathrm{~L}$ cada. O experimento foi realizado em um delineamento inteiramente ao acaso, com cinco tratamentos e quatro repetições. Os tratamentos consistiram em incluir de forma parcial e total o óleo de palma, sendo a inclusão de 0,$0 ; 1,5 ; 3,0 ; 4,5$ e 6,0\%. Foram observadas concentrações de ácidos graxos monoinsaturados e gorduras saturadas no óleo de palma, observando elevada quantidade de palmítico, oléico e linoléico. No desempenho zootécnico foram observadas diferenças significativas para as variáveis peso final, comprimento total, ganho em peso, taxa de crescimento específico e fator de condição. Não foram observadas diferenças significativas para atrato-palatabilidade das dietas. Conclui-se que a inclusão de no mínimo 3,0\% ou mais de óleo de palma em substituição ao óleo de soja na fase de masculinização de pós-larvas de tilápia, contribui para a melhora dos parâmetros produtivos.

Palavras-chave: Nutrição de peixes; Desempenho; Lipídios, Oreochromis niloticus. 


\section{Resumen}

La investigación tuvo como objetivo evaluar los efectos de la sustitución del aceite de soja por aceite de palma en la dieta de postlarvas de tilapia del Nilo, sobre el rendimiento y la atraabilidad de los alimentos, así como determinar el perfil de ésteres metílicos de ácidos grasos del aceite de palma. Se utilizaron 400 postlarvas de tilapia del Nilo siete días después de la eclosión, distribuidas en 20 tanques de fibra de vidrio de 20 L cada uno. El experimento se realizó en un diseño completamente aleatorio, con cinco tratamientos y cuatro repeticiones. Los tratamientos consistieron en incluir parcial y totalmente aceite de palma, siendo la inclusión de 0.0; 1,5; 3,0; 4,5 y 6,0\%. Se observaron concentraciones de ácidos grasos monoinsaturados y grasas saturadas en aceite de palma, observándose altas cantidades de palmítico, oleico y linoleico. En el desempeño zootécnico, se observaron diferencias significativas para las variables peso final, longitud total, ganancia de peso, tasa de crecimiento específico y factor de condición. No se observaron diferencias significativas para el atractivo y la palatabilidad de las dietas. Se concluye que la inclusión de al menos 3.0\% o más de aceite de palma para reemplazar el aceite de soja en la etapa de masculinización postlarva de la tilapia contribuye a la mejora de los parámetros de producción.

Palabras clave: Nutrición de peces; Rendimiento; Lípidos, Oreochromis niloticus.

\section{Introduction}

Fish farming in Brazil has been growing steadily and, among freshwater species, tilapia is responsible for $60 \%$ of the national production, with more than 486 thousand tons produced in 2020 (Peixe BR, 2021).

Among the commercially grown tilapia species, Nile tilapia (Oreochromis niloticus) is the most widely used in intensive systems in Brazil. This is due to its rapid growth and good quality meat (Furuya et al., 2008). In addition, because of its omnivorous feeding habit, tilapia easily accepts feed from the initial period to the termination phase (Boscolo et al., 2008).

Feeding is considered the main cost within an aquaculture sector, mainly in the intensive production of fish. The use of lipids in fish diet has the special advantage of being a low-cost energy supply (Boscolo et al., 2008; Juancey, 2000). In addition to providing substrates for energy production, lipids are sources of essential fatty acids and are structural components of cell membranes acting as transporters for other nutrients such as fat-soluble vitamins (Garcia et al., 2013). Therefore, deficiency of fatty acids can impair production, reducing growth and increasing mortality (Garcia et al., 2013; Glencross, 2009).

The use of fish oil in feed is considered an important source of essential fatty acids of the n-3 and n-6 family (Ng \& Wang, 2011). However, its availability is becoming limited due to the decline of fish stocks (Péron et al., 2010; Silva Júnior et al., 2011), which brings economic implications, making necessary the use of alternative sources such as vegetable oil for animal nutrition (Figueiredo- Silva et al., 2005).

The production of vegetable oil has been growing steadily, is a significant portion of food production. In addition, the inclusion of vegetable oils can bring benefits to the animal's performance (Pereira et al., 2011), improving the use of the protein that is consumed, providing essential fatty acids for the development of the fish (Martino et al., 2002 ). Soy oil is the vegetable lipid most used in animal nutrition, which has essential fatty acids for the development of fish. This oil can be compared with palm oil, which has been playing a significant role in animal nutrition, being used as a source of energy and essential fatty acids, and contributing to the absorption of fat-soluble vitamins (Tomkins \& Drackley, 2010). There are several benefits of palm oil, being a rich source of beta-carotene that gives it its characteristic reddish-orange color, being a great precursor of vitamin A for the body. Palm oil is also rich in vitamin E, antioxidants such as tocopherol and tocotrienol, as well as a variety of saturated and unsaturated fatty acids, with emphasis on palmitic (C16: 0), oleic (C18: 1) and linoleic (C18: 2n 6) fatty acids (NG, 2002; Grimaldi et al., 2005).

Some authors have studied the effects of palm oil on the diet of fish. Bahurmiz et al. (2007) found that the replacement of up to $100 \%$ of palm oil by fish oil in the diet of red hybrid tilapia (Oreochromis sp.) Has no negative effects on performance and also does not influence the deposition of fatty acids in muscle tissue and digestibility of nutrients. MacedoViegas and Contrera-Guzman (1998) observed that diets containing more than 3\% palm oil for tambaqui (Colossoma 
macropoтит) improved weight and length gain and had better protein efficiency and nitrogen retention efficiency. Legendre et al. (1995) and $\mathrm{Ng}$ et al. (2000) used palm oil at various levels in catfish (Clarias gariespinus) and Tortensen et al. (2000) for Atlantic salmon (Salmo salar), finding positive results for the growth and efficiency of using the diet when compared to fish fed diets containing fish oil.

Lipids play an important role in the growth phase of fish, being essential for their development, in which the use of vegetable oils becomes the main source of nutrients for this phase (Wilson, 1995; Hayashi et al., 2002; Boscolo et al., 2008;). It is observed that soy oil can be replaced by other vegetable oils without causing zootechnical damage, allowing compensatory animal gain (Nwanna \& Bolarinwa, 2000i).

Studies evaluating the use of palm oil in the diet of tropical fish in the initial phase are still scarce, and studies involving its use are necessary to establish viability. Therefore, the aim of this work was to evaluate the effects of replacing soybean oil with palm oil in post-larval diets of Nile tilapia to evaluate the effects on zootechnical performance and attractiveness-palatability.

\section{Methodology}

This research can be characterized as an experimental study (Pereira, et al., 2018). The experiment was carried out at the Aquaculture Laboratory of the Aquaculture Management Study Group - GEMAq, at the State University of West Parana UNIOESTE - Toledo Campus. Four hundred post-larvae Nile tilapias were used, 7 days after hatching with initial mean weight of $28 \pm 5 \mathrm{mg}$. The post-larvae were distributed in 20 cylindrical-tapered glass fiber tanks $(20 \mathrm{~L}$ each), equipped with a water recirculation system and thermostat for temperature control. At the end of the day, the tanks were siphoned to remove any feed leftovers.

Water quality control was performed using the YSI Professional Plus Multiparameter Water Quality Meter (YSI, Pro Plus, Yellow Springs-Ohio, USA), where water temperature $\left(26.3 \pm 1.66^{\circ} \mathrm{C}\right)$, dissolved oxygen $(7.5 \pm 0.06 \mathrm{mg} \mathrm{L}-1)$ and $\mathrm{pH}$ $(7.4 \pm 0.04)$ were monitored. The values of the variables remained within the acceptable range for tropical fish farming (Tavares, 1995).

Five isoproteic (42\% crude protein) and isoenergetic rations (3500.00 Kcal digestible energy) were prepared, with inclusion of palm oil, replacing soybean oil at the same inclusion rates of $0.0,1.5,3.0,4.5$ and $6.0 \%$ (Table 1) The inclusion of palm oil took into account the nutritional recommendations proposed by Furuya (2010) for Nile tilapia. 
Table 1. Ingredients, chemical characteristics and inclusion levels of the experimental diets.

\begin{tabular}{|c|c|c|c|c|c|}
\hline \multirow{2}{*}{$\begin{array}{c}\text { Ingredients } \\
(\%)\end{array}$} & \multicolumn{5}{|c|}{ Level of inclusion \% } \\
\hline & 0.0 & 1.5 & 3.0 & 4.5 & 6.0 \\
\hline Soybean meal $45 \%$ & 40.00 & 40.00 & 40.00 & 40.00 & 40.00 \\
\hline Fish meal $(60 \%)$ & 20.00 & 20.00 & 20.00 & 20.00 & 20.00 \\
\hline Soybean protein concentrate $(60 \%)$ & 11.89 & 11.89 & 11.89 & 11.89 & 11.89 \\
\hline Sour Rice & 7.22 & 7.22 & 7.22 & 7.22 & 7.22 \\
\hline Corn gluten & 6.00 & 6.00 & 6.00 & 6.00 & 6.00 \\
\hline Corn grain & 3.88 & 3.88 & 3.88 & 3.88 & 3.88 \\
\hline Soy oil & 6.00 & 4.50 & 3.00 & 1.50 & 0.00 \\
\hline Palm oil & 0.00 & 1.50 & 3.00 & 4.50 & 6.00 \\
\hline Dicalcium phosphate & 3.51 & 3.51 & 3.51 & 3.51 & 3.51 \\
\hline Premix ${ }^{1}$ & 1.00 & 1.00 & 1.00 & 1.00 & 1.00 \\
\hline L-Threonine $98 \%$ & 0.31 & 0.31 & 0.31 & 0.31 & 0.31 \\
\hline DL-Methionine $99 \%$ & 0.04 & 0.04 & 0.04 & 0.04 & 0.04 \\
\hline Regular salt & 0.30 & 0.30 & 0.30 & 0.30 & 0.30 \\
\hline Choline chloride & 0.10 & 0.10 & 0.10 & 0.10 & 0.10 \\
\hline Antifungal 2 & 0.10 & 0.10 & 0.10 & 0.10 & 0.10 \\
\hline Vitamin C3 & 0.10 & 0.10 & 0.10 & 0.10 & 0.10 \\
\hline Antioxidant 4 & 0.02 & 0.02 & 0.02 & 0.02 & 0.02 \\
\hline Total & 100 & 100 & 100 & 100 & 100 \\
\hline \multicolumn{6}{|c|}{ Chemical composition analyzed \% } \\
\hline & 0.0 & 1.5 & 3.0 & 4.5 & 6.0 \\
\hline Dry matter & 93.31 & 93.31 & 93.40 & 91.31 & 93.47 \\
\hline Protein & 39.91 & 43.39 & 41.74 & 42.16 & 42.98 \\
\hline Ether extract & 9.66 & 9.52 & 9.43 & 9.63 & 9.07 \\
\hline Mineral matter. & 11.16 & 10.82 & 12.28 & 12.22 & 12.31 \\
\hline Crude fiber & 6.86 & 7.70 & 8.97 & 7.05 & 6.55 \\
\hline Gross Energy (Kcal) & 4.448 & 4.495 & 4.299 & 4.209 & 4.213 \\
\hline
\end{tabular}

1 Warranty Levels per kg of product - Premix (DSM-Roche®): Vit. A, 24,000 IU; Vit. D3, 6,000 IU;

Vit. E, 300 mg; Vit. K 3, 30 mg;Vit.B1, 40 mg; Vit. B2, 40 mg; Vit. B6, 35 mg; Vit. B12, 80 mg; B.C.

Folic acid, $12 \mathrm{mg}$; Pantothenate Ca, $100 \mathrm{mg}$; Vit. C, $600 \mathrm{mg}$; Biotin, $2 \mathrm{mg}$; Hill, $1000 \mathrm{mg}$; Niacin;

Iron, 200 mg; Copper, 35 mg; Manganese, 100 mg; Zinc, 240 mg; Iodine, 1.6 mg; Cobalt, 0.8 mg.

${ }^{2}$ Calcium Propionate.

"Vitamin C - Rovimix" Stay-35.

4BHT - Butyl Hydroxy Toluene.

Source: Authors (2021).

The ingredients used to make the experimental diets were ground in a hammer mill (Vieira, MCS 280, Tatuí-SP, Brazil), with a $0.3 \mathrm{~mm}$ sieve and mixed with the oils. The diet was offered to the animals as extruded pellet, and hormone was added (17-alpha-methyltestosterone) for masculinization of the animals. The fish underwent a five-day adaptation period for experimental diets and conditions and soon after this period, the animals were fed four times a day $(8 \mathrm{~h} 00,11 \mathrm{~h} 00,14 \mathrm{~h} 00$ and 17h00) according to the adaptive period, for apparent satiety for 40 days.

The fatty acid methylation of the total lipids of the ingredients was performed according to the method of Hartman 
and Lago (1973) and carried out at the laboratory of water and food of the department of chemistry of the State University of Maringá - Brazil. For analysis, approximately $0.030 \mathrm{~g}$ of total lipids (palm oil) were added in an esterification tube. The esterified sample was kept in the refrigerator until phase separation. The supernatant was collected and transferred to a vial for further chromatographic analysis.

The fatty acid methyl esters (FAME) were separated on a Trace Ultra 3300 Thermo brand gas chromatograph equipped with a flame ionization detector and CP-7420 fused silica capillary column (Select FAME, $100 \mathrm{~m}$ long, $0.25 \mathrm{~mm}$ internal diameter and $0.25 \mu \mathrm{m}$ cyanopropyl). Retention times and peak areas of the FAME were determined using the ChromQuest TM 5.0 software. Fatty acids were identified by comparing their retention times with standard 189-19 of known composition (Sigma - USA). The absolute quantification of FAME was performed by internal standardization using tricosanoic acid methyl ester (23: 0), Sigma - USA, and calculations performed according to the method of Joseph \& Ackman (1992). Theoretical correction factors (Visentainer, 2012) were used to determine the concentration values. The amount of fatty acid in the samples was calculated in mg compared to total lipids (mg g-1LT AG) using Equation 1.

$$
\mathrm{Mx}=\frac{\text { Ax } \cdot \text { Mp } \cdot \text { Fct }}{\text { Ap } \cdot \text { Ma } \cdot \text { Fcea }}
$$

Equation 1

Where: $\mathrm{Mx}$ is the mass of fatty acid $\mathrm{X}$ in $\mathrm{mg} \mathrm{g}-1$ of total lipids, Ax is the peak area of the fatty acid $\mathrm{X}$, Ap is the peak area of the internal standard (23: 0), Mp is the mass of internal standard added to the sample in mg, MA is the mass of the sample in $\mathrm{g}$, Fct is the theoretical correction factor of the flame ionization detector (DIC) and Fcea is the conversion factor of methyl ester to fatty acid.

After the experimental period, the fish were food deprived for 24 hours to empty the gastrointestinal tract, then anesthetized with benzocaine at a dose of 75 mg.L-1 (Gomes et al., 2001) and individual measurements of weight (g) and total length $(\mathrm{cm})$ were performed.

The performance data evaluated: initial weight $(\mathrm{g})$; final weight $(\mathrm{g})$; weight gain (final body weight - initial body weight); condition factor ((body weight, g/total length $\left.\left.{ }^{3}, \mathrm{~cm}\right) \times 100\right)$; specific growth rate (\% day-1) ((ln final weight) - (ln initial weight) / time X 100); survival (\%) (100 X (final fish number / initial fish number)).

To evaluate the attractiveness of the diets, 12 Nile tilapia fry weighing $1 \mathrm{~g}$ were used, where they were allocated to aquariums with a capacity of 30 liters, one individual per aquarium, where they were separated by a barrier, isolating them from any movement in the laboratory. The animals stayed two days in the aquarium for acclimation before the test of feed choice. For this test, three diets were used, one control (without addition of oil) and two tests (soybean oil and palm oil). For this experiment, a commercial microextrused feed containing $380 \mathrm{~g} / \mathrm{kg}$ of crude protein and without addition of oil in its composition was used, then $6 \%$ of each oil tested was pulverized on this food for the test.

In each aquarium were attached three feeders made with silicone hoses, remaining in one of the three corners of the aquarium. In the morning and afternoon (8:00 a.m. and 2:00 p.m.), 20 grains of feed of each treatment were offered in each feeder at random. The frequency of visits to each feeder and the number of granules ingested were observed, where each aquarium was timed for a period of 10 minutes.

The experimental design was completely randomized with five treatments and four replicates for the zootechnical performance test and three treatments and four replicates for palatability. The data was analyzed with ANOVA and when significant differences were observed, the Tukey averages comparison test was applied, with 5\% significance. The analyzes were performed using the Statistic 7.1 software (2005). 


\section{Results}

Concentrations of monounsaturated, polyunsaturated and saturated fatty acids in palm oil were observed, and the most prominent fatty acids were palmitic (C16: 0), oleic (C18: 1n-7) and linoleic acid (C18: 2n-6 ) (Table 2).

Table 2. Profile of fatty acids (\%) in palm and soybean oil.

\begin{tabular}{cccc}
\hline Fatty Acids & Name & Palm Oil* & Soybean Oil** \\
\hline C12:0 & Lauric & 0.34 & - \\
C14:0 & Myristic & 0.65 & 0.06 \\
C15:0 & Pentadecyl & 0.06 & - \\
C16:0 & Palmitic & 33.51 & 9.90 \\
C16:1 & Palmitoleic & 0.19 & 0.04 \\
C17:0 & Margaric & 0.09 & 0.10 \\
C18:0 & Stearic & 3.90 & 3.94 \\
C18:1n-9c & Oleic & 48.63 & 23.44 \\
C18:1n-7 & - & 0.50 & - \\
C18:2n-6 & Linoleic & 11.28 & 52.92 \\
C18:3n-3 & Alpha-linoleic & 0.38 & 7.60 \\
C20:0 & Arachidonic & 0.28 & 0.48 \\
C20:1n-9 & Cis-11-Eicosanoic & 0.21 & 0.12 \\
AGPI & Polyunsaturated fat & 11.65 & 60.64 \\
AGMI & Monounsaturated fat & 49.53 & 23.92 \\
AGS & Saturated Fat & 38.82 & 4.01 \\
\hline *Analyzed values. & & & \\
* Literature values (Zambiazi et al., 2007). & &
\end{tabular}

Significant differences $(\mathrm{P}<0.05)$ were observed for the variables final weight $(\mathrm{FW})$, total length (TL), weight gain (WG), specific growth rate (SGR) and condition factor (CF) (Table 3). Except for TL and FC, the inclusion of 3 and $6 \%$ of palm oil in the diet resulted in better results compared to the diet containing only soybean oil. Diets containing 3; 4.5 and $6 \%$ of palm oil increased fish total length, while for $\mathrm{CF}$, higher results were observed compared to the control diet for fish fed with diet containing $100 \%$ palm oil.

Table 3. Mean and standard deviation of the mean zootechnical performance of post-larvae of Nile tilápia fed diets containing palm oil.

\begin{tabular}{|c|c|c|c|c|c|}
\hline Variables* & $0.0 \%$ & $1.5 \%$ & $3.0 \%$ & $4.5 \%$ & $6.0 \%$ \\
\hline IW(mg) & 28 & 28 & 28 & 28 & 28 \\
\hline $\mathrm{FW}(\mathrm{mg})$ & $789 \pm 0.06$ & $869 \pm 0.09$ & $956 \pm 0.04$ & $929 \pm 0.04$ & $982 \pm 0.06$ \\
\hline $\mathrm{TL}(\mathrm{cm})$ & $35.99 \pm 1.39$ & $37.45 \pm 1.90$ & $38.98 \pm 0.55$ & $38.69 \pm 1.20$ & $38.96 \pm 0.98$ \\
\hline WG (mg) & $760 \pm 0.06$ & $840 \pm 0.09$ & $928 \pm 0.04$ & $900 \pm 0.04$ & $953 \pm 0.06$ \\
\hline $\operatorname{SGR}(\%)$ & $9.44 \pm 0.23$ & $9.71 \pm 0.33$ & $9.99 \pm 0.13$ & $9.91 \pm 0.15$ & $10.06 \pm 0.19$ \\
\hline $\mathrm{CF}$ & $2.19 \pm 0.17$ & $2.31 \pm 0.15$ & $2.45 \pm 0.10$ & $2.42 \pm 0.06$ & $2.51 \pm 0.10$ \\
\hline SUR. (\%) & $91.25 \pm 10.30$ & $95.00 \pm 4.08$ & $96.25 \pm 4.78$ & $95.00 \pm 5.77$ & $97.5 \pm 5.0$ \\
\hline
\end{tabular}

Mean \pm SD. IW = Initial Weight; FW = Final Weight; TL = Total Length; WG = Weight Gain; $\mathrm{SGR}=$ Specific Growth Rate; CF = Condition Factor; SUR = Survival. Source: Authors (2021).

No significant differences were observed $(\mathrm{P}>0.05)$ for palatability of the diets tested (Table 4). 
Table 4. Palatability of diets containing soybean oil and palm oil. Means followed by the same letter do not differ statistically by the Tukey test $(\mathrm{P}>0.05)$.

\begin{tabular}{ccccc}
\hline Variables $(\%)$ & T1 & T2 & T3 & Effect (P) \\
\cline { 2 - 5 } & $3.29 \pm 2.14 \mathrm{a}$ & $3.87 \pm 2.57 \mathrm{a}$ & $3.04 \pm 2.13 \mathrm{a}$ & 0.1481 \\
Visit Frequency & $8.05 \pm 5.92 \mathrm{a}$ & $9.02 \pm 6.23 \mathrm{a}$ & $6.40 \pm 5.60 \mathrm{a}$ & 0.0668 \\
Granules Ingested &
\end{tabular}

$\mathrm{T} 1=$ diet containing $6 \%$ soybean oil; $\mathrm{T} 2=$ diet containing $6 \%$ palm oil; T3 = oil-free diet. Source: Authors (2021).

\section{Discussion}

The fatty acid composition (FA) obtained for palm oil used in this study was similar to values obtained by NRC (1993) and Ng et al. (2003), which reported high values for palmitic, oleic and linoleic acid. These fatty acids influence the productive performance of Nile tilapia (Furuya, 2010), being metabolized in large quantities, generating energy for fish growth (Henderson et al., 1984; Henderson \& Altamar, 1989).

There are several studies on the requirement of polyunsaturated fatty acids for fish, varying according to species (Ribeiro et al., 2012). Nile tilapia has a requirement of $0.5 \%$ of linoleic fatty acid (C18: 2n-6) (Martino, 2003), an essential fatty acid for Nile tilapia, responsible for improving productive parameters (Twibell et al., 2000; Santos et al., 2007). In the ingredient of the present study, an amount of $11.28 \%$ of $\mathrm{C} 18: 2 \mathrm{n}-6$ was observed, which meets the needs of Nile tilapia and can be a positive factor for performance variables. The inclusion of palm oil in the experimental diets positively influenced the variables of final weight (FW), total length (TL), weight gain (WG), specific growth rate (SGR), and condition factor of Nile tilapia. In a study conducted by Ayise et al., 2014, using levels of palm oil in the Nile tilapia diet, they observed a greater weight gain and specific growth rate, in the animals that received bedding with the inclusion of $6 \%$ oil of palm. Uliana et al. (2001), significant results were found for WG, SGR, TL, FW of Rhamdia quelen larvae submitted to a diet of 5\% canola oil. Similar results by Ferreira et al. (2014), verified the influence of oregano oil to Astyanax altiparane, obtaining positive results for weigh gain and specific growth rate.

The use of coconut oil in diets for common carp larvae (Cyprinus carpio L.), obtained positive results for survival and SGR, justifying the high levels of oleic acid present (Fontagné et al., 1999). However, Ferraz (2015) reported a reduction in the survival rate of yellow-tailed lambari (Astyanax altiparanae) fingerlings fed palm and coconut oil, which, according to the author, is due to the low levels of polyunsaturated fatty acids found in these oils, reflecting in the immunological fitness of the fish.

The results of this study can also be justified by the low stocking density of post-larvae in the experimental period, where the fish appropriately used the lipids as energy source, taking advantage of the essential fatty acids for their development. Tolussi et al. (2010) working with Brycon insignis larvae observed that the increase in storage density causes changes in lipid metabolism and fatty acid profile. This parameter, besides compromising lipid metabolism causing low growth, can promote high stress (Portella, et al., 2013). In diets deficient in essential fatty acids, a decrease in growth may occur (Glencross, 2009), a fact that did not occur in the present study due to the high concentration of these fatty acids in palm oil.

When working with diets containing alternative sources, a great difficulty is observed in the acceptability of fish feed, which may be related to palatability (Rodríguez-Serna, 1996). The attractiveness of the diets did not show significant differences between the treatments, but it can be observed that through the average values there was a greater consumption of the feed containing palm oil, being the most attractive among the treatments tested. Therefore, the results found for the zootechnical performance of Nile tilapia can also be justified by the attractiveness/palatability of the diets containing palm oil, allowing a high consumption, positively influencing the evaluated variables. In agreement, Azevedo (2013), working with 
palm pie in diets for tilapia juveniles, observed an increase in the daily intake values of the feed, which may have been influenced by the palatability of the diet. According to NRC (1994), the use of lipids in feed improves palatability and reduces nutrient loss.

$\mathrm{Ng}$ et al. (2000) agrees that palm oil can be used in tropical fish feed without compromising growth, making feeding more efficient. However, the inclusion of palm oil in the diet of Nile tilapia post-larvae proved to be effective for zootechnical performance, presenting positive effects in all treatments.

\section{Conclusion}

Based on the information obtained in the present study, it was concluded that the inclusion of the inclusion of at least $3 \%$ palm oil to replace soybean oil in the sexual determination phase of tilapia post-larvae contributes to the improvement of productive parameters, allowing the use of palm oil as an alternative source of energy in the feeding of this species.

New studies are important to evaluate the use of palm oil for Nile tilapia, especially in the other stages of cultivation, in addition to evaluating the fatty acid composition of the carcass.

\section{Ethical approval}

All procedures performed in studies involving animals were in accordance with the ethical standards of the institution or practice in which the studies were conducted. All applicable international, national, and/or institutional guidelines for care and use of animals were followed by the authors.

\section{References}

Azevedo, R. V., Tonini, W. C. \& Braga, L. G. T. (2013). Óleo e torta de dendê em rações para juvenis de tilápia-do-nilo. Pesquisa Agropecuária Brasileira. Brasília. 48(8), 1028-34. https://doi.org/10.1590/S0100-204X2013000800031.

Bahurmiz, O. M. \& NG, W. K. (2007). Effects of dietary palm oil source on growth, tissue fatty acid composition and nutrient digestibility of red hybrid tilapia, Oreochromis sp., raised from stocking to marketable size. Aquaculture 262 382-392. https://doi.org/10.1016/j.aquaculture.2006.11.023.

Boscolo, W. R., Signor, A. A., Signor, A., Feiden, A., Reidel, A. \& Boscolo, R. J. (2008). Substituição parcial e total do óleo de soja pelo óleo de tilápia em rações para larvas de tilápia do Nilo (Oreochromis niloticus). Semina: Ciências Agrárias, Londrina. 29(3), 707-12. http://dx.doi.org/10.5433/16790359.2008v29n3p707.

Ferraz, R. B. (2015). Fontes de óleos em dietas para lambari-do-rabo-amarelo (Astyana altiparanae). Viçosa, Brasil, Minas Gerais. 67f. (Dissertação de Mestrado. Universidade Federal de Viçosa, UFV). https://www.locus.ufv.br/handle/123456789/6702.

Ferreira, P.M.F., Nascimento, L.S.; Dias, D. C., Moreira, D. M. V., Salaro, A. L., Freitas, M. B. D., Carneiro, A. P. S., Zuanon, J. A. S. (2014). Essential Oregano Oil as a Growth Promoter for the Yellowtail Tetra, Astyanax altiparanae. Journal of the World Aquaculture Society, 45, 28-34. https://doi.org/10.1111/jwas.12094.

Figueiredo Silva, A., Rocha, E., Dias, J., Silva, P., Rema, P., Gomes, E., \& Valente, L. M. P. (2005). Partial replacement of fish oil by soybean oil lipid distribution and liver histology in European sea bass (Dicentrarchus labrax) and rainbow trout (Oncorhynchus mykiss) juveniles. Aquaculture Nutrition. 11, 147-155. https://doi.org/10.1111/j.1365-2095.2004.00337.x.

Fontagné, S., Pruszynski, T., Corraze, G., \& Bergot, P. (1999). Effect of coconut oil and tricaprylin vs. triolein on survival, growth and fatty acid composition of common carp (Cyprinus carpio L.) larvae. Aquaculture 179 241-251. https://doi.org/10.1016/S0044-8486(99)00193-3.

Furuya, W. M., Fujii, K. M., Santos, L. D., Silva, T. S. C., Silva, L. C. R., \& Michelato, M. (2008). Exigência de fósforo disponível para juvenis de tilápia-donilo (35 a 100 g). Revista Brasileira de Zootecnia, 37(9), 1517-1522. https://doi.org/10.1590/S1516-35982008000600001.

Furuya, W. M., (2010). Tabelas brasileiras para nutrição de tilápia. GFM, Toledo, Paraná.

Garcia, A. S., Gonçalves, L. U., Cavalli, R. O., \& Macedo-Viegas, E. M. (2013). Lípidios. In: Nutriaqua: Nutrição e alimentação de espécies de interesse para a aquicultura brasileira. Fracalossi, D. M., Cyrino, J. E. P. Florianópolis: Sociedade Brasileira de Aquicultura e Biologia Aquática. 375 p.

Glencross, D. B. (2009). Exploring the nutritional demand for essential fatty acids by aquaculture species. Reviews in Aquaculture 1: 71-124. https://doi.org/10.1111/j.1753-5131.2009.01006.x.

Gomes, L. C., Chippari-Gomes, A. R., Lopes, N. P., Roubach, R., \& Araujo-Lima, A. A. R. M. (2001). Efficacy of benzocaine as anesthetic in juvenile tambaqui Colossoma macropomum. Journal of World Aquaculture Society 32, 426-431. https://doi.org/10.1111/j.1749-7345.2001.tb00470.x. 
Grimaldi, R., Gonçalves, L. A. G., \& Ando, M. Y. (2005). Otimização da reação de interesterificação química do óleo de palma. Química Nova, $28(4), 633$. https://doi.org/10.1590/S0100-40422005000400015.

Hartman, L. \& Lago, R. C. (1973). Rapid preparation of fatty acid methyl esters from lipids. Laboratory Practice, 22, 475-476.

Hayashi, C., Boscolo, W. R., Soares, C. M., \& Meurer, F. (2002). Exigência de proteína digestível para larvas de tilápia do Nilo (Oreochromis niloticus) durante a reversão sexual. Revista Brasileira de Zootecnia, 31(2), 823-828. https://doi.org/10.1590/S1516-35982002000400003.

Henderson, R. J. \& Altamar, S. M. (1989). Seasonal changes in the lipid composition of herring in relation to gonad maturation. Journal of the Marine Biological. Association of the UK 69, 307 - 313. https://doi.org/10.1017/S0025315400029441.

Henderson, R. J., Sargent, J. R., \& Hopkins, C. C. E. (1984). Changes in the content and fatty acid composition of lipid in an isolated population of the capelin Mallotus villosus during sexual maturation and spawning. Marine Biology 78, 255 - 263. https://doi.org/10.1007/BF00393011.

Joseph, J. D. \& Ackman, R. G. (1992). Capillary column gas chromatographic method for analysis of encapsulated fish oils and fish oil ethyl esters: Collaborative study. Journal of AOAC International, 75, 488-506. https://doi.org/10.1093/jaoac/75.3.488.

Juancey, K. Nutritional requirements. (2000). In: Beveridge, M. C. M., McAndrew, B. J. (Ed.). Tilapias: biology and exploitation. Stirling: Institute of Aquaculture - University of Stirling. 327-375.

Legendre, M., Kerdchuan, N., Corraze, G., \& Bergot, P. (1995). Larval rearing of an African catfish Heterobranchus longifilis (Teleostei, Clariidae): effect of dietary lipids on growth, survival and fatty acid composition of fry. Aquatic Living Resources. 8, $355-363$. https://doi.org/10.1051/alr:1995040.

Macedo-Viegas, E.M. \& Contreras-Guzman, E. (1998). Effect of sources and levels of dietary lipids on growth, body composition, and fatty acids of the tambaqui (Colossoma macropomum). World Aquaculture, 29(10), 66-70.

Martino, R. C. (2003). Exigências e cuidados da adição de lipídeos em rações para peixes e a sua importância para o homem - Parte 2. Rev. Panorama da Aquicultura, 13(75), 58-60.

National Research Council (NRC). (1993). Nutrient Requirements of Fish and Shrimp. The National Academic Press Washington, DC, USA.

National Reseach Council (NRC). (1994). Nutrient Requirements of poultry. 9 ed. Washington, D.C.: National Academy: State University. 16 p.

Ng, W. K., Tee, M. C., \& Boey, P. L. (2000). Evaluation of crude palm oil and refined palm olein as dietary lipids in pelleted feeds for a tropical catfish Mystus nemurus (Cuvier and Valenciennes). Aquaculture Resources. 31, 337 - 347. https://doi.org/10.1046/j.1365-2109.2000.00437.x.

Ng, W. K. (2002). Palm oil, alternative lipid source in aquaculture feeds. The Advocate.

Ng, W. K., Lim, P. K., \& Boey, P. L. (2003). Dietary lipid palm oil sources affects growth, fatty acid composition and muscle $\alpha$-tocopherol concentration of African catfish, (Clarias gariepinus). Aquaculture, v.215, p.229-243.

Ng, W. K., \& Wang, Y. (2011). Inclusion of crude palm oil in the brood stock diets of female Nile tilapia, Oreochromis niloticus, resulted in enhanced reproductive performance compared to broodfish fed diets with added fish oil or linseed oil. Aquaculture, v.314, p.122-131. https://doi.org/10.1016/j.aquaculture.2011.01.034.

Nwanna, L. C., \& Bolarinwa, T. O. (2000). Effects of different dietary oils on the growth and economic performance of tilapia Oreochromis niloticus. In: International Symposium of Tilápia Aquaculture, 5., 2000. Rio de Janeiro. Proeceedings... Rio de Janeiro: WAS. p. 227-234.

Peixe BR - Associação Brasileira de Piscicultura. (2019). Anuário Peixe BR da Piscicultura, 148p.

Pereira, S. A., Shitsuka, D. M., Parreira, F. J. \& Shitsuka, R. (2018). Metodologia da pesquisa científica. UFSM.

Péron, G., Mittaine, J. F., \& Le Gallic, B. (2010). Where do fishmeal and fish oil products come from? An analysis of the conversion ratios in the global fishmeal industry. Marine policy, 34, 815-820. https://doi.org/10.1016/j.marpol.2010.01.027.

Portella, M. C., Leitão, N. J., Takata, R., \& Lopes, T. S. (2013). Alimentação e Nutrição de Larvas. In: Nutriaqua: Nutrição e alimentação de espécies de interesse para a aquicultura brasileira. Fracalossi, D. M., Cyrino, J. E. P. Florianópolis: Sociedade Brasileira de Aquicultura e Biologia Aquática. 375 p.

Ribeiro, P. A. P., Melo, D. C., Costa, L. S., \& Teixeira, E. A. (2012). Manejo nutricional e alimentar de peixes de água doce. 92p.

Rodríguez-Serna, M., Olvera Novoa, M. A.; \& Carmona-Osalde, C. (1996). Nutritional value of animal by product meal in practical diets for Nile tilapia, Oreochromis niloticus (L.) fry. Aquaculture Research, 27, 67 73. https://doi.org/10.1111/j.1365-2109.1996.tb00967.x

Ssantos, L. D., Furuya, W. M., Matsushita, M., Silva, L. C. R., Silva, T. S. C., \& Botaro, D. (2007). Ácido linoléico conjugado (CLA) em dietas para tilápiado-nilo: desempenho produtivo, composição química e perfil de ácidos graxos. Revista Brasileira de Zootecnia. 36(5), 1481-1488. https://doi.org/10.1590/S1516-35982007000700004.

Silva Júnior, R. F., Nova, W. V., Farias, J. L., Costa-Bonfim, C. N., Tesser, M. B., Druzian, J. I., Correia, E. S., \& Cavalli, R. O. (2011). Substituição do óleo de peixe por óleo de soja em dietas para beijupirá (Rachycentron canadum). Arquivo Brasileiro de Medicina Veterinária e Zootecnia. 63(4), 980-987. https://doi.org/10.1590/S1516-35982007000700004.

Statsoft, Inc. (2005). Statistica (data analysis software system), version 7.1. <https://www.statsoft.com>,

Tavares, L. H. S. (1995). Limnologia aplicada à aquicultura. FUNEP/UNESP. Ed. 72 p. 
Research, Society and Development, v. 10, n. 14, e510101422099, 2021

(CC BY 4.0) | ISSN 2525-3409 | DOI: http://dx.doi.org/10.33448/rsd-v10i14.22099

Tolussi, C. E., Hilsdorf, A. W. S., Caneppele, D., \& Moreira. (2010). The effects of stocking in physiological parameters and growth of the endangered teleost species piabanha. Brycon insignis (Steindachner, 1877). Aquaculture 310:221-228. https://doi.org/ 10.1016/j.aquaculture.2010.10.007.

Tortensen, B. E., Lie, O., \& Froyland, L. (2000). Lipid metabolism and tissue composition in Atlantic salmon (Salmo salar L.) —effects of capelin oil, palm oil and oleic-enriched sunflower oil as dietary lipid sources. Lipids 35, 653 - 664. https://doi.org/10.1007/s11745-000-0570-6.

Tomkins, T. \& Drackley, J. K. (2010). Applications of palm oil in animal nutrition. Journal of oil palm research. 835-845.

Twibell, R. G., Watkins, B. A., \& Rogers, L. (2000). Effects of dietary conjugated linoleic acids on hepatic and muscle lipids in hybrid striped bass. Lipids, 35, 155-161. https://doi.org/10.1007/BF02664765.

Uliana, O., Silva, J. H. S., \& Neto, J. R. (2001). Diferentes fontes de lipídios testadas na criação de larvas de jundiá (Rhamdia quelen), pisces, pimelodidae. Ciência Rural, 31(1). https://doi.org/10.1590/S0103-84782001000100021.

USDA, Foreing Agriculture Service. (2017). Oilseeds: World markets and trade. Office of Global Analysis. United States Department of Agriculture.

Visentainer, J. V. (2012). Aspectos analíticos da resposta do detector de ionização em chama para ésteres de ácidos graxos em biodiesel e alimentos. Química Nova, 35, 274-279. https://doi.org/10.1590/S0100-40422012000200008.

Wilson, R. P. (1995). Lipid nutrition of finish: nutrition and utilization technology. In: Lim, C., Sessa, D. J. (Ed.). Nutrition and utilization technology in aquaculture. Champaign: AOAC Press. p. 74-81.

Zambiazi, R. C., Przybylski, R., Zambiazi, M. W., \& Mendonça, C. B. (2007). Fatty acid composition of vegetable oils and fats. B. CEPPA, 25(1), 111-120. http://dx.doi.org/10.5380/cep.v25i1.8399. 